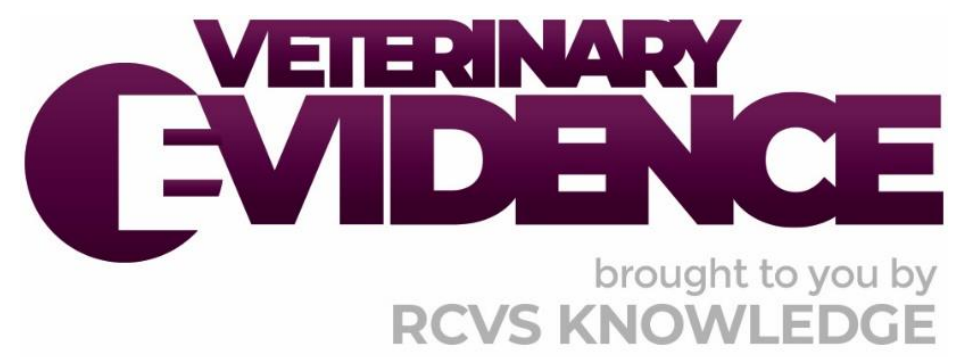

\title{
Comparing Rest Alone to Bandaging and Rest in Horses With Superficial Digital Flexor Tendinopathy
}

\section{A Knowledge Summary by}

Rafael Alzola BVMS, MSc, Cert AVP (EP, ESST, ESO, VDI) MRCVS ${ }^{1}$

Sarah L. Freeman BVetMed, PhD, CertVA, CertVR, CertES, DipECVS, FHEA, FRCVS²

\footnotetext{
${ }^{1}$ Oakham Veterinary Hospital, Nottingham University, Ashwell Road, Oakham, Rutland, LE15 7QH

${ }^{2}$ School of Veterinary Medicine and Science, University of Nottingham, Sutton Bonington Campus, Leicestershire, LE12 5RD

*Corresponding Author (rafael.alzola@oakhamvethospital.co.uk)
}

ISSN: 2396-9776

Published: 06 Aug 2019

in: Vol 4, Issue 3

DOI: http://dx.doi.org/10.18849/ve.v4i3.234

Reviewed by: Matthew Stewart (MVetClinStud, PhD, FACVS) and Peter Clegg (MA Vet, MB, PhD, CertEO, DipECVS, MRCVS)

Next Review Date: Sep 11th 2020 


\section{PICO question}

In horses with superficial digital flexor tendonitis is bandaging and rest compared to rest alone more effective at promoting healing?

\section{Clinical bottom line}

There is currently a lack of scientific evidence to suggest that bandaging promotes effective tendon healing following injury. However, rigid bandages significantly limit lesion propagation in equine superficial digital flexor (SDF) tendinopathies. The result of this PICO question suggests that a short period (ten days) of cast immobilisation during the initial inflammatory phase of the injury improves prognosis by limiting lesion propagation. The level of confidence in the outcomes from the body of evidence in the four studies identified is moderate.

\section{Clinical scenario}

An 8-year-old Thoroughbred gelding used for National Hunt racing presents with a recent history of swelling of the right forelimb (RF) flexor tendons (bowed tendon) following morning training. The horse is only slightly RF lame in straight line on hard ground but he resents palpation of the superficial digital flexor tendon (SDFT). Ultrasonographic examination revealed a SDF tendinitis with a core lesion affecting 4 zones (2A-3B); the maximal injury zone (MIZ) is located at $2 \mathrm{~B}$. The lesion at the $\mathrm{MIZ}$ is anechoic (score 1 ), affected $<25 \%$ of the cross-sectional area (score 1 ) and between $\geqq 50-75 \%$ of the longitudinal pattern (score 3 ) of the tendon (Alzola et al., 2017). You discuss all treatment options, including medical and surgical options, with the owner and trainer. However, the horse raced only in low price claiming races and the trainer is not very fond of him. The decision is made to either treat the injury conservatively and cheaply or retire the horse from racing. What evidence is there to inform the owner and the trainer that bandaging and rest compared to rest alone is more effective in cases with SDF tendinopathy?

\section{The evidence}

There is no evidence within the literature to support that any type of bandaging enhances tendon healing during the resting period following a tendon injury. However, bandaging (cast bandage) has a significant effect limiting lesion propagation during the initial inflammatory phase in SDF tendinopathies. The quality of the evidence comparing rigid versus nonrigid bandages to limit lesion propagation is of moderate quality and reliability. In different randomised controlled trials lesion propagation was significantly reduced using a short period (10 days) of cast immobilisation compared to a two layer Robert Jones bandage or no bandage. However, the studies only included either surgically or collagenase-induced lesions and need validating in naturally occurring injuries. Potential short or long-term detrimental effects of immobilisation (cast) were not investigated in these studies.

\section{Summary of the evidence}

\section{David (2011)}

Population: $\quad$ Six mature Standardbred horses with an average age of $52 \pm 13$ months (mean \pm s.d.) and weight of $489 \pm 28 \mathrm{Kg}$. Including only horses that were free of lameness and absence of any current or previous SDFT injuries was confirmed ultrasonographically 


\begin{tabular}{|c|c|}
\hline Sample size: & 12 forelimbs with surgically induced core lesions in the SDFT \\
\hline Intervention details: & $\begin{array}{l}\text { - Core lesions in both front SDFTs were surgically created mimicking } \\
\text { clinical lesions through a stab incision into the SDFT for a length of } 6 \\
\mathrm{~cm} \text { using an arthroscopic obturator (diameter } 3.5 \mathrm{~mm} \text { ) and burr } \\
\text { (diameter } 4 \mathrm{~mm} \text { ) with horses under general anaesthesia. } \\
\text { - One randomly chosen forelimb per horse ( } \mathrm{N}=6 \text { ) was immobilised } \\
\text { with a half-limb cast while the opposite limb was placed in a two } \\
\text { layer Robert Jones bandage (control; Robert Jones bandages were } \\
\text { changed every third day): six cast and six control forelimbs. } \\
\text { - } 10 \text { days post surgery the cast, Robert Jones bandage and skin } \\
\text { sutures were removed and a stable bandage (single layer inelastic } \\
\text { bandage with padding) was placed on each forelimb for } 5 \text { days. } \\
\text { - Horses were box rested until day } 28 \text { post surgery, followed by daily } \\
\text { hand walking (10 minutes) until the end of the study (day } 42 \text { ) when } \\
\text { they were euthanised. }\end{array}$ \\
\hline Study design: & Prospective experimental study \\
\hline Outcome studied: & $\begin{array}{l}\text { Objective assessment } \\
\text { Variables measured: } \\
\text { - Computerised ultrasonographic tissue characterisation (UTC) was } \\
\text { used with a standardised protocol on days, } 0,10,15,21,28,35 \text { and } \\
42 \text { post surgery to evaluate the lesions: } \\
\text { A. Sonographic visualisation: Lesion length (cm) } \\
\text { B. Stability of the echo pattern: Lesion width (\%) } \\
\text { - Macroscopic digital photographs of the transverse slices of the } \\
\text { tendons obtained on day } 42 \text { were used to calculate the macro } \\
\text { length of the lesion for each forelimb. }\end{array}$ \\
\hline $\begin{array}{r}\text { Main findings: } \\
\text { (relevant to PICO question): }\end{array}$ & $\begin{array}{l}\text { Lesions were } 19 \% \text { shorter (length) and } 57 \% \text { smaller (width) in cast } \\
\text { compared to the control (Robert Jones bandage) forelimbs ( } P \leq 0.04) \text { : } \\
\text { - UTC findings (mean } \pm \text { s.e.): } \\
\text { - Lesion length }(\mathrm{cm}) \text { : Cast }(6.13 \pm 0.12) \text { - Control }(7.30 \pm 0.21) \\
\text { - Lesion width }(\%) \text { : Cast }(6.90 \pm 0.64) \text { - Control }(10.85 \pm 1.22) \\
\text { - Macroscopic evaluation (mean } \pm \text { s.e.): } \\
\text { - Lesion length (cm): Cast }(7.00 \pm 0.36) \text { - Control }(8.33 \pm 0.33)\end{array}$ \\
\hline
\end{tabular}




\begin{tabular}{|l|l|}
\hline Limitations: & $\begin{array}{l}\text { - Core lesions in SDFTs were created surgically and might not } \\
\text { correspond to naturally occurring injuries or behave in the same } \\
\text { way. } \\
\text { - Extra load on the controlled limbs due to the cast on the opposite } \\
\text { limbs was not calculated and its effect was not investigated. } \\
\text { - Potential short or long-term detrimental effects of immobilisation } \\
\text { (cast) were not investigated. } \\
\text { - Although Robert Jones bandages were changed every third day, } \\
\text { confirmation that desired pressure was achieved and maintained } \\
\text { with the bandage was not performed (pressure sensors). }\end{array}$ \\
\hline
\end{tabular}

\begin{tabular}{|l|l|}
\hline \multicolumn{2}{|l|}{ Bosch (2010) } \\
\hline Population: & $\begin{array}{l}12 \text { mature Dutch Warmblood horses with mean age } 9.3 \text { years (range } \\
7-14 \text { years) and weight of } 600 \mathrm{Kg} \text { (range } 550-650 \mathrm{Kg} \text { ) that were } \\
\text { euthanised for reasons not related to tendon disorders. Absence of } \\
\text { tendon disorders was confirmed by physical palpation and } \\
\text { postmortem ultrasonography }\end{array}$ \\
\hline Sample size: & $\begin{array}{l}22 \text { forelimbs with either surgical or collagenase-induced core lesions } \\
\text { in the SDFT }\end{array}$ \\
\hline
\end{tabular}




\begin{tabular}{|c|c|}
\hline Intervention details: & $\begin{array}{l}\text { Forelimbs were divided in three experiments: } \\
\text { - Collagenase-induced tendon lesions: } \\
\text { 1. Control group - to study the propagation of lesion } \\
\text { (unloaded conditions): } \mathrm{n}=6 \text { limbs. Limbs were left without } \\
\text { loading } 8 \mathrm{~h} \text {. } \\
\text { 2. Loaded group - to study the effect of cyclical loading and } \\
\text { the effect of immobilisation: six pairs of limbs (12 limbs). } \\
\text { Limbs were subjected to } 5000 \text { unload load cycles over } 8 \mathrm{~h} \\
\text { period using a pneumatic limb loading device (1800 N, } 600 \\
\mathrm{~N} / \mathrm{s} \text { ): } \mathrm{n}=6 \text { limbs cast; } 6 \text { limbs uncast. } \\
\text { Lesions were created injecting bacterial collagenase type I } \\
\text { (1500 u) (ultrasound guided) into the core of the SDFT: } \\
\text { Surgically-induced tendon lesions: } \\
\text { 3. to study the propagation of lesions under cyclical loading: } \\
\mathrm{n}=4 \text { limbs (No control group, all limbs were loaded). } \\
\text { Lesions were created through a stab incision into the SDFT } \\
\text { over a length of } 7-8 \mathrm{~cm} \text { (marked) using an arthroscopic burr } \\
\text { (diameter } 3.5 \mathrm{~mm} \text { ). All limbs were subjected to } 5000 \text { unload } \\
\text { load cycles over } 48 \mathrm{~h} \text { period using a pneumatic limb loading } \\
\text { device ( } 1800 \mathrm{~N}, 600 \mathrm{~N} / \mathrm{s} \text { ). }\end{array}$ \\
\hline Study design: & Prospective experimental study \\
\hline Outcome studied: & $\begin{array}{l}\text { Objective assessment } \\
\text { Variables measured: } \\
\text { - Collagenase-induced lesions: } \\
\text { o Ultrasonographic evaluation of the lesions on all limbs. } \\
\text { o Macroscopic evaluation: average values of the length }(\mathrm{cm}) \\
\text { and width (\%) of the lesions. } \\
\text { o Force at rupture ( } \mathrm{N}) \text { between uncast and cast limbs (loaded } \\
\text { group only.) } \\
\text { - Surgically induced lesions: } \\
\text { o Macroscopic evaluation: No difference in length }(\mathrm{cm}) \text { of the } \\
\text { lesions before and after cyclic loading. No further } \\
\text { investigation performed. }\end{array}$ \\
\hline
\end{tabular}




\begin{tabular}{|c|c|}
\hline $\begin{array}{r}\text { Main findings: } \\
\text { (relevant to PICO question): }\end{array}$ & $\begin{array}{l}\text { - In surgically induced lesions in dead limbs where there is no } \\
\text { enzymatic stimulation (only mechanical stimulation) there is no } \\
\text { propagation. Therefore, lesion propagation is caused by the } \\
\text { combination of enzymatic and mechanical stimulation. } \\
\text { - In this ex vivo model casting appeared effective to reduce the } \\
\text { enlargement of the original collagenase-induced tendon lesions } \\
\text { after cyclical loading ( } 2.85 \pm 0.59 \mathrm{~cm} \text { ) compared to uncast limbs } \\
(4.33 \pm 0.63 \mathrm{~cm} \text { ) but did not affect ultimate tendon strength. }\end{array}$ \\
\hline Limitations: & $\begin{array}{l}\text { - This is an ex vivo model that does not replicate the in vivo lesion. } \\
\text { - SDFT lesions were created surgically or enzymatically and do not } \\
\text { correspond to naturally occurring injuries or behave in the same } \\
\text { way. } \\
\text { - Loading regimen used in this experiment is low (1800 N) compared } \\
\text { with the loading applied at walk ( } 3600 \mathrm{~N}) \text {. } \\
\text { - Relationship between type of lesion (surgical or collagenase- } \\
\text { induced) and force at rupture was not investigated. } \\
\text { - Potential detrimental effects of immobilisation (cast) were not } \\
\text { investigated. }\end{array}$ \\
\hline
\end{tabular}

Smith (2002)

Population: Postmortem equine forelimbs from Thoroughbred type horses with no signs of distal limb injury

Sample size: Seven postmortem equine forelimbs 


\begin{tabular}{|c|c|}
\hline Intervention details: & $\begin{array}{l}\text { - Forelimbs were loaded in a pneumohydraulic loading machine } \\
\text { (Hydraulic Test Rig): } \\
\text { Force acting on the limb was recorded through plate and } \\
\text { shear beam load cell (TW560) mounted under the hoof. } \\
\text { Metacarpophalangeal (MCP) joint angle was recorded with a } \\
\text { goniometer. } \\
\text { Force and angle data were amplified via strain gauge } \\
\text { amplifiers. Data were captured and stored for analysis using a } \\
\text { personal computer. } \\
\text { - Forelimbs were initially loaded to a peak force of } 5 \text { kN over } 5 \\
\text { seconds and then unloaded at the same rate. Two further loading } \\
\text { cycles were then applied during which forelimb force and MCP joint } \\
\text { angle were recorded. } \\
\text { - Five support methods (gamgee, neoprene, Dalmar support system } \\
\text { [settings } 1,2 \text { and } 3 \text { ] and three layered bandage with and without } \\
\text { splint) were applied in the same sequence for each forelimb. } \\
\text { - Each forelimb was loaded twice for each support method, only the } \\
\text { second loading cycle was used in the analysis. } \\
\text { - A control loading (bare forelimb) was recorded in between support } \\
\text { methods. }\end{array}$ \\
\hline Study design: & Prospective experimental study \\
\hline Outcome studied: & $\begin{array}{l}\text { Objective assessment } \\
\text { Forelimb force }(\mathrm{kN}) \text { at specific MCP joint angles }\left(215^{\circ}, 220^{\circ}, 225^{\circ} \text {, }\right. \\
\left.230^{\circ}, 235^{\circ}, 240^{\circ}, 245^{\circ}, 250^{\circ}\right)\end{array}$ \\
\hline
\end{tabular}




\begin{tabular}{|c|c|}
\hline $\begin{array}{l}\text { Main findings: } \\
\text { (relevant to PICO question): }\end{array}$ & $\begin{array}{l}\text { Three layered bandage with or without (only at high MCP joint angles } \\
\geqq 245^{\circ} \text { ) a palmar splint, and the Dalmar tendon support boot both } \\
\text { provide significant resistance to MCP joint extension. This will reduce } \\
\text { the strain experienced by the SDFT, deep digital flexor tendon (DDFT) } \\
\text { and suspensory ligament allowing tendon/ligament healing. In } \\
\text { addition, the Dalmar tendon support boot can be used in exercising } \\
\text { horses (mechanical protection). } \\
\text { Forelimb force MCP joint angle relationship for all the different } \\
\text { support techniques compared to an isolated forelimb (ex vivo): } \\
\text { Neoprene boot or a simple gamgee bandage have no significant } \\
\text { effect on the forelimb force MCP joint angle relationship. } \\
\text { Three layered bandage: } \\
\text { - without palmar splint has a significant effect only at high } \\
\text { MCP joint extension angles } \geqq 245^{\circ} \text {. } \\
\text { - with palmar splint has a significant effect at MCP joint } \\
\text { extension angles } \geqq 230^{\circ} \text {. } \\
\text { Dalmar tendon support boot: } \\
\text { - Setting } 1 \text { and } 2 \text { have a significant support at high MCP joint } \\
\text { extension angles } \geqq 245^{\circ} \text {. } \\
\text { - Setting } 3 \text { provides significant support at MCP joint } \\
\text { extension angles } \geqq 225^{\circ} \text {. }\end{array}$ \\
\hline Limitations: & $\begin{array}{l}\text { - This is an ex vivo model that does not replicate what occurs in live } \\
\text { animals. } \\
\text { - Further research (in vivo model) is required to confirm that some } \\
\text { support methods (three layered bandage with or without palmar } \\
\text { splint and Dalmar tendon support boot) are useful to manage } \\
\text { tendon/ligament injury throughout healing and rehabilitation. } \\
\text { - Absence of any current or previous tendon injuries in the } \\
\text { investigated limbs was not confirmed with palpation and } \\
\text { ultrasonography. } \\
\text { - Loading force in study was } 10 \mathrm{~N} / \mathrm{Kg} \text { body mass but it would have } \\
\text { been more appropriate to use the peak MCP joint angle during } \\
\text { stance ( } 216^{\circ} \text { at walk, } 232^{\circ} \text { at trot, } 228^{\circ} \text { at lead canter, } 238^{\circ} \text { at non } \\
\left.\text { lead canter and } 250^{\circ} \text { at gallop (McGuigan, } 2001\right) \text { ). } \\
\text { - Long-term consequences of reduction of MCP joint extension vs. } \\
\text { fibre alignment during the healing process in injured horses was not } \\
\text { investigated. }\end{array}$ \\
\hline
\end{tabular}




\begin{tabular}{|c|c|}
\hline \multicolumn{2}{|l|}{ Kicker (2004) } \\
\hline Population: & $\begin{array}{l}\text { Mature Warmblood horses (seven mares, two stallions, } 17 \text { geldings) } \\
\text { were included with average age of } 11 \pm \text { years (mean } \pm \text { s.d.) and weight } \\
\text { of } 533 \pm 53 \mathrm{Kg} \text {. }\end{array}$ \\
\hline Sample size: & 26 mature warmblood horses \\
\hline Intervention details: & $\begin{array}{l}\text { Kinematics (six camera video system with a sampling frequency of } 120 \\
\mathrm{~Hz} \text { ) of the forelimb fetlock joint angle at walk and trot on a treadmill } \\
\text { when each horse was wearing three different support boots (Sport } \\
\text { Medicine boots, Eskadron and TSM AED Reha- and Sport bandages), } \\
\text { one protective boot (Streifamasche, predefined tension } 50 \mathrm{~N} \text { ) and } \\
\text { without boots (control group): } \\
\text { - Constant speed for each horse (Walk: } 1.6 \pm 0.1 \mathrm{~m} / \mathrm{sec} \text {; Trot: } 3.3 \pm 0.2 \\
\text { m/sec; mean } \pm \text { s.d.) } \\
\text { - Recorded: } 30 \text { seconds of walk and trot } \\
\text { - At walk: Minimum of } 20 \text { cycles } \\
\text { - At trot: Minimum of } 30 \text { cycles }\end{array}$ \\
\hline Study design: & Prospective experimental study \\
\hline Outcome studied: & $\begin{array}{l}\text { Objective assessment } \\
\text { Variables measured: } \\
\text { - Maximum extension of the fetlock joint: minimal virtual dorsal } \\
\text { fetlock joint angle }\left(^{\circ}\right) \\
\text { - Moment at which maximum extension occurred in the stride cycle: } \\
\text { occurrence time of minimal virtual dorsal fetlock joint angle (\% of } \\
\text { the stride cycle) }\end{array}$ \\
\hline $\begin{array}{r}\text { Main findings: } \\
\text { (relevant to PICO question): }\end{array}$ & $\begin{array}{l}\text { Support boots reduce maximum extension of the fetlock, which can } \\
\text { be assumed to reduce tension in the suspensory apparatus and SDFT. } \\
\text { Delay of the moment of maximal extension may be relevant in } \\
\text { reducing dynamic forces. } \\
\text { More specifically: } \\
\text { - At walk: two of the support boots reduced the maximum extension } \\
\text { angle by } 0.8^{\circ} \text { (Eskadron) and } 0.9^{\circ} \text { (TSM AED Reha- and } \\
\text { Sportsbandages) (P<0.05) and one type of boot (TSM AED Reha- and } \\
\text { Sportsbandages) also delayed the occurrence of maximal extension } \\
\text { within the stride cycle (theorical reduction of the dynamic load of } \\
\text { the SDFT; no clinical significance). } \\
\text { Minimal virtual dorsal fetlock joint angle for the control group } \\
\text { (unprotected) at walk: } 136.26^{\circ} \pm 6.44^{\circ} \text { (mean } \pm \text { s.d.) }\end{array}$ \\
\hline
\end{tabular}




\begin{tabular}{|c|c|}
\hline & $\begin{array}{l}\text { - At trot: all support/protective boots reduced the maximum } \\
\text { extension angle by } 0.56^{\circ}-1.44^{\circ}(P<0.05) \text { and none delayed } \\
\text { significantly the occurence of maximal extension within the stride } \\
\text { cycle. } \\
\text { Minimal virtual dorsal fetlock joint angle for the control group } \\
\text { (unprotected) at trot: } 122.73^{\circ} \pm 6.3^{\circ} \text { (mean } \pm \text { s.d.) }\end{array}$ \\
\hline Limitations: & $\begin{array}{l}\text { - Absence of any current or previous tendon injuries or lameness in } \\
\text { the investigated limbs was not confirmed with palpation and } \\
\text { ultrasonography. } \\
\text { - Treadmill speed was not standardised for all horses which could } \\
\text { have affected the results. } \\
\text { - A further group including horses recovering from a tendon injury } \\
\text { would have provided useful information for this study. }\end{array}$ \\
\hline
\end{tabular}

\section{Appraisal, application and reflection}

This PICO question focuses on the benefits of bandaging and rest versus rest alone for treating superficial digital tendonitis in equids. The four relevant studies found to fit the PICO criteria were prospective experimental studies and the evidence gained from them is reported above. This represents evidence of moderate quality and reliability as only one of the two in vivo studies, contrary to the in vitro, mimic the naturally occurring injuries.

Superficial digital flexor (SDF) tendinopathy is a common injury in equine athletes, following undefined periods of accumulation of exercise and age related microdamage without any preceding clinical signs. Complete tendon healing is a long process, re-injury rates are high, and these injuries are potentially career ending for the most severe cases. Lesion size is directly linked to prognosis, with poorer prognosis for larger SDFT injuries (Alzola et al., 2018). Therefore, tendinopathy is a significant health and welfare concern in horses.

In clinical situations, SDF tendinopathies have a tendency to propagate (length and width) significantly during the first few weeks after initial injury due to the combination of enzymatic and biomechanical stimulation (Bosch et al., 2010). The tendon healing process follows the general pattern of wound healing with overlapping phases: inflammatory, proliferative and maturation phase. Lesion propagation occurs during the initial inflammatory phase (approx. 10-21 days) when the disrupted tendon fibres are digested by proteolytic enzymes like metalloproteinases and then removed by phagocytosis ( Leadbetter, 1992 and Palmer et al., 1994). Biomechanical loading, even at very low levels, induces propagation but only in conjunction with the activity of proteolytic enzymes (Bosch et al., 2010). Therefore, results from ex vivo cadaveric studies should be interpreted with caution as inflammation cannot be reproduced.

There is no evidence within the literature to support that any type of bandaging promotes tendon healing during the resting period. However, bandaging has a significant effect on limiting lesion propagation. Ex vivo (Bosch et al., 2010) and in vivo (David et al., 2012) studies have proven that motion restriction of the lower limb with a rigid bandage (cast bandage) significantly reduces lesion propagation during the acute phase improving prognosis. Nonsteroidal anti-inflammatory drugs (NSAIDs) also influence lesion propagation by inhibiting inflammation and concomitantly proteolytic enzyme activity (Mehallo et al., 2006), but review of this evidence is beyond the scope of this knowledge summary.

Flexor tendons (SDFT and DDFT) and the suspensory ligament remain loaded for as long as the limb is weightbearing, even in box rested horses. Biomechanical loading on the SDFT is maximal during hyperextension of the metacarpophalangeal (MCP) joint. In the standing horse, resistance to extension of the MCP joint is a passive process; an increase in MCP joint angle will result in an increase strain in the tendons and ligaments (Bartel et al., 1978 and Shoemaker et al., 1991). 
Multiple external support techniques (rigid/nonrigid) have been used to resist overextension of the MCP joint to reduce potentially damaging peak loads and strains to the SDFT after injury or to reduce re-injury risk. Contrary to rigid bandages, in an ex vivo study, nonrigid support systems (conventional bandages) did not provide significant resistance to MCP joint extension during the stance phase or walk (Smith et al., 2002). Reducing MCP joint extension is essential in the box rest period for tendon healing. Controversially in an in vivo study, support boots did reduce significantly MCP joint extension during walk and trot (Kicker et al., 2004). Using ultrasonography in an ex vivo equine model of acute SDFT injury (collagenase-induced model), lesion length was significantly greater $(P<0.05)$ in the repetitively loaded forelimbs compared to the cast (half forelimb cast) or unloaded forelimbs that were almost identical (Bosch et al., 2010). In this study, there was no difference in lesion width or in the force at rupture ( $F$ failure) between uncast and cast limbs. In a more recent in vivo study using computerised ultrasonographic tissue characterisation to evaluate surgically induced SDFT lesions, limb casting reduced significantly lesion size (length and width) compared to bandaging with a 2-layer Robert Jones bandage $(\mathrm{P} \leq 0.04)$. These findings were also corroborated during macroscopic evaluation of the lesions. In this study, cast immobilisation for ten days during the early phase of tendon healing effectively reduced lesion propagation compared to bandaging (David et al., 2012). Although there is no evidence in equids regarding the optimal immobilisation time during the rest period, ten day cast immobilisation is in accordance with the human literature that recommends casting only during the acute phase of tendon injuries for about 5-7 days (Buckwalter, 1995).

Cast immobilisation during the acute inflammatory phase provides constant counter-pressure to longitudinal, transverse and rotational forces and avoids MCP hyperextension (Smith et al., 2002) avoiding lengthening of injured structures and slowing down the "pump" phenomenon at the tendon level (Cribb \& Scott, 1995), hence preventing lesion propagation. In addition, cast immobilisation will also limit secondary SDFT injuries (Kannus et al., 2003).

Some human studies have shown that stress deprivation of the SDF tendon induced by long-term cast immobilisation could negatively affect tendon biochemical and biomechanic properties, as well as tendon repair (Yasuda \& Hayashi, 1999 and Aspenberg, 2007). However, the former effects are time dependent and, therefore, reversible with remobilisation. Short term immobilisation does not result in significant reduction of physiological properties in healthy tendons (Christensen et al., 2008). Likewise, half limb casting does not seem to produce a complete stress shielding effect in equids, providing some degree of mechanical stimulation (David et al., 2012), which is known to avoid tendon degeneration (Nabeshima et al., 1996).

An early and gradual increase in physical load improves healing by enhancing synthesis of collagen during the proliferation phase and alignment of collagen fibres in the remodelling phase (Dowling et al., 2000 and Aspenberg, 2007). After cast removal, the support provided to the MCP joint should be reduced gradually using less rigid support systems: modified Robert Jones distal limb bandage with a contoured palmar splint, Dalmar tendon support boot (Smith et al., 2010) or some support boots (Eskadron or TSM AED Reha- and Sportsbandages) (Kicker et al., 2004). This will avoid sudden increase in tissue loading throughout healing tissues. Unfortunately, not all of these systems will be practical to use in exercising horses during rehabilitation. Lesion length and lesion width is bound to increase after support removal in both cast and bandage, although these changes were significantly shorter and smaller in casted lesions (David et al., 2012). After cast removal, rest should be continued until the initial inflammatory response subsides (approx. 4-6 weeks in total) and followed by a well designed exercise programme to achieve optimal alignment of collagen fibres (Kicker et al., 2004).

In conclusion, bandaging does not enhance tendon healing during the rest period (acute inflammatory phase) but a short period (ten days) of cast immobilisation improves prognosis for SDF tendinopathies by preventing lesion propagation with minimal negative effects to the tendon. Cast immobilisation period must be followed by early functional therapy to enhance tendon healing using support systems to reduce extension MCP joint and subsequently tension in the SDFT. 


\section{Search Strategy \\ Databases searched and dates covered: \\ CAB Abstracts on OVID Platform (1973-2018 Week 35) \\ PubMed via the NCBI website (1910-September 2018)}

Search terms: CAB Abstracts:

1. (equine or equines or horse or horses or equus or equid or equids or mare or mares or broodmare or broodmares or pony or ponies or filly or fillies or colt or colts or yearling or yearlings or stallion or stallions or thoroughbred or thoroughbreds or Standardbred or Standardbreds or racehorse or racehorses or race horse or race horses).mp. or exp horses/or exp equus/or exp equidae/ or exp mares/or exp colts/or exp foals/ or exp stallions/ or exp thoroughbred/ or exp racehorses/.

2. ("superficial digital flexor tendon" or "superficial digital flexor tendons" or "digital flexor tendon" or "digital flexor tendons" or "superficial digital flexor tendonitis" or "superficial digital flexor tendinitis" or "superficial digital flexor tendinopathy" or SDFT or "superficial digital tendon" or "superficial digital tendonitis" or "superficial digital tendinitis" or "superficial digital tendinopathy" or SDF or tendonitis or tendinitis).

3. (bandages or bandaging or bandaged or bandage or binding or bind or bound or binds or dresses or dressing or dressed or dressings or cast or casting).mp. or exp bandages/.

4. (rest or resting or rested or rests).

5. 1 and 2 and ( 3 or 4$)$.

\section{PubMed:}

1. equine $O R$ equines $O R$ horse $O R$ horses $O R$ equus $O R$ equid OR equids OR mare OR mares OR broodmare OR broodmares OR pony OR ponies OR filly OR fillies OR colt OR colts $O R$ yearling $O R$ yearlings $O R$ stallion OR stallions $O R$ thoroughbred OR thoroughbreds OR Standardbred OR Standardbreds OR racehorse OR racehorses OR race horse OR race horses.

2. 'superficial digital flexor tendon' OR 'superficial digital flexor tendons' OR 'digital flexor tendon' OR 'digital flexor tendons' $O R$ 'superficial digital flexor tendonitis' OR 'superficial digital flexor tendinitis' OR 'superficial digital flexor tendinopathy' OR SDFT OR 'superficial digital tendon' OR 'superficial digital tendonitis' OR 'superficial digital tendinitis' OR 'superficial digital tendinopathy' OR SDF OR tendonitis OR tendinitis

3. bandages $O R$ bandaging $O R$ bandaged $O R$ bandage $O R$ binding OR bind OR bound OR binds OR dresses OR dressing OR dressed OR dressings OR cast OR casting.

4. rest $O R$ resting $O R$ rested $O R$ rests. 


\section{Exclusion / Inclusion Criteria}

Exclusion: Non English or Spanish language publications or articles not relevant to the PICO. No study was excluded based on the study type.

Inclusion: Studies available in English or Spanish relevant to the PICO

\begin{tabular}{|c|c|c|c|c|c|}
\hline \multicolumn{6}{|c|}{ Search Outcome } \\
\hline Database & $\begin{array}{l}\text { Number of } \\
\text { results }\end{array}$ & $\begin{array}{c}\text { Excluded - } \\
\text { Not in English } \\
\text { or Spanish }\end{array}$ & $\begin{array}{l}\text { Excluded - did not } \\
\text { address the PICO } \\
\text { question }\end{array}$ & $\begin{array}{l}\text { Excluded - } \\
\text { duplication }\end{array}$ & $\begin{array}{c}\text { Total relevant } \\
\text { papers }\end{array}$ \\
\hline CAB Abstracts & 77 & 16 & 58 & 0 & 3 \\
\hline PubMed & 32 & 1 & 28 & 2 & 1 \\
\hline \multicolumn{5}{|c|}{ Total relevant papers when duplicates removed } & 4 \\
\hline
\end{tabular}

\section{CONFLICT OF INTEREST}

The authors declare no conflicts of interest.

The authors extend their thanks to Myai Du for doing the abstract search to answer this PICO question.

\section{REFERENCES}

1. Alzola, R., Riggs, C.M., Gardner, D.S., and Freeman, S.L. (2017). "Ultrasonographic scoring system for superficial digital flexor tendon injuries in horses: Intra- and inter- rater variability". Vet Rec 181(24): 1-DOI: http://dx.doi.org/10.1136/vr.104233

2. Alzola, R., Easter, C., Riggs, C.M., Gardner, D.S., and Freeman, S.L. (2018). "Ultrasonographic-based predictive factors influencing successful return to racing after superficial digital flexor tendon injuries in flat racehorses: A retrospective cohort study in 469 Thoroughbred racehorses in Hong Kong." Equine Vet J 50(5): 602- DOI: $10.1111 /$ evi.12810

3. Aspenberg, P. (2007). "Stimulation of tendon repair: mechanical loading, GDFs and platelets. A minireview." Int Orthop 31(6): 783- DOI: 10.1007/s00264-007-0398-6

4. Bartel, D.L., Schryver, H.F., Lowe, J.E., and Parker, R.A. (1978). "Locomotion in the horse: a procedure 
for computing the internal forces in the digit." Am J Vet Res 39(11): 1721-

5. Bosch, G., Lameris, M.C., van den Belt, A.J., Barneveld, A., and van Weeren, P.R. (2010). "The propagation of induced tendon lesions in the equine superficial digital flexor tendon: an ex vivo study." Equine Vet J 42(5): 407- DOI: 10.1111/j.2042-3306.2010.00099.x

6. Buckwalter, J.A. (1995). "Should bone, soft-tissue, and joint injuries be treated with rest or activity?" J Orthop Res 13(2): 155- DOI: 10.1002/jor.1100130202

7. Christensen, B., Dyrberg, E., Aagaard, P., Kjaer, M., and Langberg, H. (2008). "Short-term immobilization and recovery affect skeletal muscle but not collagen tissue turnover in humans." $\underline{\mathrm{J} \text { Appl }}$ Physiol (1985) 105(6): 1845- DOI: 10.1152/japplphysiol.90445.2008

8. Cribb, A.M. and Scott, J.E. (1995). "Tendon response to tensile stress: an ultrastructural investigation of collagen:proteoglycan interactions in stressed tendon." J Anat 187(Pt 2): 423-

9. David, F., Cadby, J., Bosch, G., Brama, P., van Weeren, R., and van Schie, H. (2012). "Short-term cast immobilisation is effective in reducing lesion propagation in a surgical model of equine superficial digital flexor tendon injury." Equine Vet J 44(5): 570- DOI: 10.1111/j.2042-3306.2011.00513.x

10. Dowling, B.A., Dart, A.J., Hodgson, D.R., and Smith, R.K., (2000). "Superficial digital flexor tendonitis in the horse." Equine Vet J 32(5): 369- DOI: https://doi.org/10.2746/042516400777591138

11. Kannus, P., Parkkari, J., Jarvinen, T.L., Jarvinen, T.A., and Jarvinen, M. (2003). "Basic science and clinical studies coincide: active treatment approach is needed after a sports injury." Scand J Med Sci Sports 13(3): 150- DOI: https://doi.org/10.1034/i.1600-0838.2003.02225.x

12. Kicker, C.J., Peham, C., Girtler, D., and Licka, T. (2004). "Influence of support boots on fetlock joint angle of the forelimb of the horse at walk and trot." Equine Vet J 36(8): 769-

DOI: https://doi.org/10.2746/0425164044848208

13. Leadbetter, W.B. (1992). "Cell-matrix response in tendon injury." Clin Sports Med 11(3): $533-$

14. Mehallo, C.J., Drezner, J.A., and Bytomski, J.R. (2006). "Practical management: nonsteroidal antiinflammatory drug (NSAID) use in athletic injuries." Clin J Sport Med 16(2): 170DOI: $\underline{10.1097 / 00042752-200603000-00015}$

15. Nabeshima, Y., Grood, E.S., Sakurai, A., and Herman, J.H. (1996). "Uniaxial tension inhibits tendon collagen degradation by collagenase in vitro." J Orthop Res 14(1): $123-$

DOI: https://doi.org/10.1002/jor.1100140120

16. Palmer, S.E., Genovese, R., Longo, K.L., Goodman, N., and Dyson, S. (1994). "Practical management of superficial digital flexor tendinitis in the performance horse." Vet Clin North Am Equine Pract 10(2): 425- DOI: https://doi.org/10.1016/S0749-0739(17)30363-2

17. Shoemaker, R.S., Bertone, A.L., Mohammad, L.N., and Arms, S.W. (1991). "Desmotomy of the accessory ligament of the superficial digital flexor muscle in equine cadaver limbs." Vet Surg 20(4): 245- DOI: https://doi.org/10.1111/i.1532-950X.1991.tb01254.x

18. Smith, R.K., McGuigan, M.P., Hyde, J.T., Daly, A.S., Pardoe, C.H., Lock, A.N., and Wilson, A.M. (2002). "In vitro evaluation of nonrigid support systems for the equine metacarpophalangeal joint." Equine Vet J 34(7): 726- DOI: https://doi.org/10.2746/042516402776250423 
19. Yasuda, K. and Hayashi, K. (1999). "Changes in biomechanical properties of tendons and ligaments from joint disuse." Osteoarthritis Cartilage 7(1): 122- DOI: 10.1053/joca.1998.0167

\section{Acknowledgement}

RCVS Knowledge was supported in producing this Knowledge Summary by an educational grant from Petplan Charitable Trust. 


\section{EVIIDEFeE

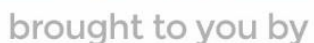 \\ RCVS KNOWLEDGE}

\section{Intellectual Property Rights}

Authors of Knowledge Summaries submitted to RCVS Knowledge for publication will retain copyright in their work, and will be required to grant RCVS Knowledge a non-exclusive license of the rights of copyright in the materials including but not limited to the right to publish, re-

publish, transmit, sell, distribute and otherwise use the materials in all languages and all media throughout the world, and to license or permit others to do so.

\section{Disclaimer}

Knowledge Summaries are a peer-reviewed article type which aims to answer a clinical question based on the best available current evidence. It does not override the responsibility

of the practitioner. Informed decisions should be made by considering such factors as individual clinical expertise and judgement along with patient's circumstances and owners' values. Knowledge Summaries are a resource to help inform and any opinions expressed within the Knowledge Summaries are the author's own and do not necessarily reflect the view of the RCVS Knowledge. Authors are responsible for the accuracy of the content. While the

Editor and Publisher believe that all content herein are in accord with current recommendations and practice at the time of publication, they accept no legal responsibility

for any errors or omissions, and make no warranty, express or implied, with respect to material contained within.

For further information please refer to our Terms of Use.

RCVS Knowledge is the independent charity associated with the Royal College of Veterinary Surgeons (RCVS). Our ambition is to become a global intermediary for evidence based veterinary knowledge by providing access to information

that is of immediate value to practicing veterinary professionals and directly contributes to evidence based clinical decision-making.

https://www.veterinaryevidence.org/

RCVS Knowledge is a registered Charity No. 230886.

Registered as a Company limited by guarantee in England and Wales No. 598443.

Registered Office: Belgravia House, 62-64 Horseferry Road, London SW1P 2AF

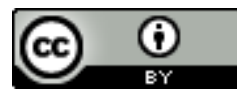

This work is licensed under a Creative Commons Attribution 4.0 International License 